\title{
Hugo Claus' Transformation of Greek Tragedy to a New Aesthetic
}

\section{Betine van Zyl Smit ${ }^{1}$ (D}

Published online: 21 March 2019

(c) The Author(s) 2019

Hugo Claus was one of the most prolific and versatile Flemish novelists, poets and playwrights of the twentieth century. He made frequent use of ancient literature in his work, sometimes in the form of allusions to Greek myth, but also by way of transforming ancient dramas into new plays for the contemporary stage. Not having received a classical education at school, Claus made use of translations and reference works to educate himself. ${ }^{1}$ While Claus's plays have an impressive performance history in his native Belgium and across Europe, there has been very little scholarly attention to his work by scholars of classical reception in the Anglophone world.

To date, there is virtually no scholarly work in English on Claus's transformation of Greek and Roman plays into Flemish, ${ }^{2}$ even though he was a dramatist who successfully adapted many ancient plays for the modern stage and on whose literary work and achievement there is a considerable body of Dutch scholarship. The most extensive examination of his engagement with ancient literature and myth is offered by Paul Claes, De Mot Zit in de Mythe: Hugo Claus en de oudheid (1984). Claes's analysis of Claus's adaptation of Senecan tragedy is followed by an examination of the Belgian's Orestes and Het Huis van Labdakos. Blindeman, In Kolonos and Borgerocco are not covered in Claes's study as they were created later. Building on the treatment by Claes and other scholarly work in Dutch, and incorporating contemporary newspaper reviews, this paper examines how Claus transformed different Greek tragedies into modern plays by making changes to the text and by innovative staging and costumes. As Claus' frequent remarks on his treatment of ancient plays in various interviews and programmes of productions show, he considered ancient

\footnotetext{
${ }^{1}$ For passages in which Claus refers to himself as an autodidact and mentions that he was inspired by the examples of Ezra Pound and T. S. Eliot in their use of antiquity in their literary works, see Claes (1984b), especially the chapter 'De Auteur als Commentator'.

2 For instance, Wright (2008) does not mention Claus' Orestes in his chapter on reception; likewise Kelly (2009) has nothing on Claus' reception of $O C$ in his section on reception.
}

Betine van Zyl Smit

abzbv@nottingham.ac.uk

1 Department of Classics and Archaeology, University of Nottingham, Nottingham, UK 
dramas as raw material for plays that commented on the contemporary modern world.

Before his turn to Greek drama, Claus was a pioneer in adapting Senecan tragedy for modern audiences. He created his own versions of Seneca's Thyestes (1966), Oedipus (1971) and Phaedra (1980). ${ }^{3}$ Claus was attracted to Seneca's tragedies precisely because of their characteristics perceived as flaws by many scholars and critics. If weaknesses such as the depiction of gruesome violence and baroque rhetoric were routinely criticized, Claus declared that he was not interested in the socalled 'classical' and perfect. It was the surreal elements he found in these plays that attracted him. ${ }^{4}$ His predilection for the unusual and the influence of Artaud's theatre of cruelty, evident in his adaptations of Senecan tragedy, remain discernible in his versions of Greek plays. The first of these was Euripides's Orestes, staged in 1976 in Antwerp. The following year saw the first of his three further versions of the Oedipus myth, Het Huis van Labdakos. This play deals with the myth in a way very different from his Oedipus, naar Seneca and incorporates elements of Sophocles's two Oedipus plays as well as his Antigone and Euripides's Phoenissae. The next version of Oedipus, Blindeman (1985), made use of his earlier adaptation of Seneca's tragedy, while In Kolonos, based on Sophocles's tragedy, which followed in the next year, completes what Paul Claes called Claus's 'oedipodie'. In 1998, Claus turned to Euripides again in Borgerocco or De dood in Borgerhout, the libretto for an opera derived from Medea and set in an immigrant community in modern Belgium.

\section{Orestes}

Claus' choice of Euripides' Orestes seems to have been based on reasons similar to his choice of Senecan tragedy. This tragedy, too, accords with his approach to drama in that it has likewise been criticized in the modern world because of its 'imperfections', not fitting the criteria of a 'proper' tragedy. Objections have been raised to its 'roller coaster plot and distinctively self-parodying tone, together with the selfconscious - even arch - awareness of the literary legacy which underlies it ${ }^{\prime}$ as well as 'its overturning of mythical tradition, its chaotic plot, the feverish nature of the characterization, its numerous violations of tragic decorum'. ${ }^{7}$ Claus embraced and enhanced all these features. A compounding factor for many critics' harsh censure of Euripides's Orestes was that it was first performed in $408 \mathrm{BC}$ and thereby exactly fifty years after Aeschylus's sublime Oresteia trilogy, which is widely regarded as one of the masterpieces of Greek literature. The Aeschylean Oresteia was already

\footnotetext{
3 See van Zyl Smit (2015) for an examination of Claus' adaptation of Senecan tragedy.

${ }^{4}$ Helen Slaney's discussion of Antonin Artaud's recognition of the affinities between his Theatre of Cruelty and Senecan drama highlights the kind of aesthetic which appealed to Artaud (Slaney 2016, pp. 228-42). Artaud's manifesto, in turn, inspired Claus.

5 Claes (1985).

6 Hall (2001, p. xx).

7 Porter (1994, p. x, pp. 1-44), has an overview of the critical history of the Orestes.
} 
a classic in Euripides' time, as is evident from its treatment in Aristophanes' Frogs, and yet Euripides had dared to give a different interpretation to that of Aeschylus by situating the action of Orestes in the interval between the second and third parts of Aeschylus' trilogy, between the Choephoroi and the Eumenides, and focusing on the events between the death of Clytemnestra and Orestes' trial in Athens. In spite of later critical disapproval, Euripides' Orestes had been one of the most performed and admired plays in antiquity, ${ }^{8}$ but its sheer audacity in presenting an original take on the punishment of Orestes and Electra for their mother's death, made it less of a favourite in the modern world. Claus found this intriguing enough to use it as a basis for creating his own modern version; one could almost say: parody. In so doing, he followed, probably unwittingly, the example of the ancient comic poet Strattis, whose Anthroporestes was most likely a comic reworking of Euripides' play. ${ }^{9}$ Claus himself said that he had few affinities with Greek tragedy, but that he had read Euripides' Orestes with a kind of pleasure, because it was modern. He described it as a masterly work with great weaknesses. It thus contained both ingredients about which he could write and an approach he could follow. ${ }^{10}$ Claes quotes from an interview he conducted with Claus, where he calls Euripides' Orestes the opposite of a harmonious, well-structured play. ${ }^{11} \mathrm{He}$ said it was told in an 'untidy' way and thus had the necessary characteristics to grip his imagination. This again confirms Claus' aesthetic predilection using ancient plays which fell outside the scope of what was regarded as conforming to classical ideals as the basis for his adaptations.

It is thus understandable that the bold approach Euripides took to the material from the aftermath of the Trojan War, familiar from other tragedies such as Aeschylus' Oresteia, Sophocles' Electra and Euripides' own Electra, appealed to Claus' imagination. Euripides offers a unique interpretation of the effect of Clytemnestra's murder by her own children, Orestes and Electra. The play is set in Argos shortly after Clytemnestra and Aegisthus have been killed. Orestes has been arrested and is awaiting trial on a charge of murdering his mother. He is suffering from the hallucination of being pursued by the Furies and is tended by his sister, Electra. They hope that when Menelaus returns he will help them, but he proves to be unwilling to help his brother's children. Orestes and Electra are sentenced to death, but given the option of taking their own lives. The plot thickens with the arrival of their grandfather, Tyndareus, who wants them punished because they took the law into their own hands. Orestes treats the old man with a shocking lack of respect. Pylades, the son of king Strophius of Phocis where Orestes grew up, is his loyal friend who has

\footnotetext{
8 Wright (2008, p. 15).

9 Wright (2008, p. 115).

10 'Met Griekse tragedies het ek weinig affiniteiten... Dit stuk [Orestes] had ik echter gelezen met een sort plezier. Omdat het modern was. Het is du seen zeer egocentrische reden. Dit is een meesterwerk met grote scheuren. Het intrigeerde mij. Het makt dingen los waardoor ik onbeschaamd kan beschrijven, omdat Euripides ze vóór mij beschreef.' Interview of Claus with J. Wijnen in De Scène September, 1976, quoted by Claes (1984b, pp. 312-13).

11 Claes (1984a, p. 86): "Wat my vooral in de Orestes aantrok was het onaffe... Het tegenovergestelde van een harmonisch goedgebouwd stuk ... het is een slordig verteld sprookje, en dat heeft alle elementen om mij te boeien'.
} 
accompanied him on his return. He is equally rebellious. He masterminds an escape plan which involves killing the hated Helen and taking her daughter Hermione hostage. In this standoff, Apollo appears as deus ex machina and resolves the situation by cancelling what has happened, including Helen's death. Orestes is ordered to go to Athens for trial and then to marry Hermione, while Electra is to marry Pylades.

Many scholars have pointed out that Euripides' Orestes is not a proper tragedy. ${ }^{12}$ It has even been suggested that the play is an experiment in genre and that Euripides was creating a new kind of hybrid play. Terms such as 'tragicomedy', 'melodrama' or 'romance' have been used to describe the play, which has the structure of Greek tragedy, but not the sad ending. ${ }^{13}$ In this Euripidean play, no one is killed (even Helen is eventually resurrected as a goddess) and no one suffers a tragic downfall. Part of the tension of the play is that at different points it seems possible that Orestes and Electra may be stoned to death, but instead the play culminates in a happy ending, marked by two weddings and reconciliation, which seems closer to the typical finale of a comedy than that of a tragedy. The playfulness of Euripides' approach is also adopted by Claus and was arguably what strongly attracted him to the play.

Paul Claes distinguishes 'enscenering', presentation or staging as the dominant approach to Claus' transformation of the Orestes. ${ }^{14}$ This view is supported and expanded by Marcel Janssens. In his review of the Orestes, he writes of 'toeëigening', appropriation, because of the emphasis on the spectacular in the production. ${ }^{15}$ Claus has certainly changed the structure of the ancient drama considerably; the emphasis on staging in this play, for instance, includes a huge cast of more than forty. But the alterations are not confined to inventive methods of staging, but also include changes to the structure and linguistic register of the original. Claus' technique of transformation from ancient drama to contemporary play includes repetition, addition, omission and replacement. ${ }^{16}$

Claus follows the broad outlines of his ancient model, but adds Agamemnon, Aigistos and Clytaimnestra, and some further, invented personae to the cast of characters. The chorus of Argive women becomes a crowd of Furies at times, and at other times a group of gossipy neighbouring women (buurvrouwen). Claus' Orestes is presented in 35 scenes. An abundance of description and stage directions combines with the words of the characters and chorus to create the new play. Claus maintained that his adaptation was quite close to the original, that he made visible a few incidents to which Euripides only referred, but that he followed the structure and the tone of the original scenes. ${ }^{17}$ Claus noted that he replaced the formal rhetoric of the original by a simpler language, so that the melodramatic side of the play and its absurdity became more prominent. ${ }^{18} \mathrm{He}$ singled out three aspects of his

\footnotetext{
12 Such as Willink (1986, p. xxii), Wright (2008, pp. 18-21), Porter (1994, p. x.)

13 Wright (2008, p. 19).

14 Claes (1984b, pp. 13-14).

15 Janssens (1976, p. 776).

16 The following discussion of the play is based on the text and reviews of the premiere of Claus's Orestes (September 1976, Antwerp, directed by Walter Tillemans).

17 Interview with Claus cited by Claes (1984b, p. 307).

18 Ibid.
} 
adaptation: that he had altered the staging by making some aspects of the ancient text visible; that he had changed the text by simplifying the language and that he had transformed the structure of the play by scrapping some scenes. ${ }^{19}$ As noted by Janssens, ${ }^{20}$ a further aspect of the play which Claus highlighted was what Aristotle would call 'the spectacular': larger than life stage sets, mass scenes and an overwhelming apotheosis. Claus' approach may be described as anarchistic in his overturning the conventions of Greek tragedy where, according to Aristotle, plot is the most important.

\section{The Staging}

As he had done with his adaptation of Senecan tragedy, Claus reduced the spoken words, especially monologues, significantly. Words are often replaced by gestures, actions or visual depictions. Already the prologue scene illustrates this technique: it has been divided into eight scenes, some of which are almost entirely visual. The text has been drastically reduced and is mostly in dialogue form. There is no parodos, since the chorus is present from the start as a heap of grey rags (als een hoop grauwe vodden, p. 8) They are the Furies who resemble ancient 'dogs with wings' (Honden met vlerken p. 8). The murder of Agamemnon, which Electra mentions briefly in Euripides' play ('Clytemnestra....a woman so far gone in iniquity that she trapped her husband in the coils of an endless cloth and killed him.' Waterfield translation p. 49, Orestes 25-6), is represented in mime in Scene 4 (pp. 11-13), where Agamemnon is first shown returning from Troy and welcomed by a beautiful woman.

Commentary on the scene is given by Orestes. Clytaimnestra leads Agamemnon to a bath and Aigistos, who has been hiding behind a curtain, emerges to help Clytaimnestra capture Agamemnon within a net. ${ }^{21}$ Clytaimnstra strikes him three times with an axe, while Aigistos stabs him furiously with a sword. However, this flashback also advances the action in the present, for, as Agamemnon is caught up in the net, the Furies throw a net over Orestes. This powerfully illustrates how helplessly confined Orestes is by the deed of his mother. He has to take revenge and, therefore, will be the victim of her murder of his father. The startling difference is, of course, that he is a living victim who has to keep on paying the price for his actions by being constantly haunted by the Furies. This scene is a clear salute to the Agamemnon of Aeschylus in that the Chorus predict in the last scene that Orestes will return to avenge his father's murder. In the next scene $(5$, p. 14), Apollo appears and orders Orestes to kill his mother and her lover or else he will be tormented by the plague. Thus Orestes' guilt is explicitly linked to an order of Apollo. Apollo is presented as an unfeeling and

\footnotetext{
19 Ibid.

20 Janssens (1976, p. 777).

21 The spelling of character names follows in each case their spelling in the respective play under discussion.
} 
frivolous god who offers Orestes his bow and arrow when the Furies beset him. When the arrows fired by Orestes disperse the Furies, Apollo bursts out laughing. He is callously having fun while Orestes is suffering.

Agamemnon's ghost also appears later in the play. When Tyndareus is confronting Orestes, Agamemnon, Clytaimnestra and Aigistos appear in bloodied garments as a visible reminder of the gruesome murders. The killing of Clytaimnestra and Aigistos is also re-enacted in a scene (21: pp. 50-51), just before the charges of murder against Orestes and Elektra are debated in the assembly of the people. The scene shows the two lovers on the same bed where Agamemnon was killed. Orestes, Pylades and Elektra enter. As his mother bares her breasts in an attempt to stop Orestes, he stabs her with his sword while the chorus of the Furies comment on the atrocity of the deed. By means of scenes sometimes, as here, interpolated from other Greek tragedies (in Choephoroi, for instance, Clytaemnestra also bares her breasts as an appeal to her son), Claus renders the background of the royal family of Argos vividly present in his play.

Another example in the play of visualizing the text is Claus' representation of the trial of Orestes in Argos, (Sc. 23 De volksvergadering (the assembly of the people) which replaces a long messenger speech in Euripides (Or. 852-95, Waterfield pp. 73-4).). Claus introduces as speaking characters those mentioned by the messenger in Euripides - Diomedes and Tyndareus - and also invents an anachronistic character called Latinus, who takes the part of the honest rustic who speaks out in defence of Orestes. He rails against the injustice of punishing Orestes, who has removed a worthless, unfaithful, promiscuous woman (waardeloze, goddeloze lichtekooi; p. 55) and deserves not punishment but rather a crown of laurel. Latinus' appeal is unsuccessful and he goes on to tell Elektra of the sentence of enforced suicide for brother and sister. A further lively enactment of a scene only narrated in the Greek drama, by the Phrygian eunuch, is the attack of Orestes and Pylades on Helen. Elektra enlists the chorus, now as women of the neighbourhood who hate Helen who has made many widows, to act as lookouts. Farcical scenes follow as the decadent Phrygian guards ineffectually defend Helen as she is chased by Orestes. This broad comedy stretches over scenes 29-32.

The radical transformation of the chorus makes visible the two levels of action within the play. The ancient chorus of women of Argos is changed into a chorus that, in some scenes, takes on the form of bat-like creatures, representing the world of the gods (the irrational Furies), while in other scenes, as mentioned above, they are the women of the neighbourhood representing human society. In this way, the chorus is more closely involved in the action, not only as commentators but also as participants. Their hatred of Helen is based on their view of her as the cause of so many deaths among the men in their families. They make explicit that ideas like those of revenge where blood calls for blood are not unreal forces moving above human life, but are rooted in the hatred of human beings. In the shape of the Furies, Orestes' feelings of guilt, which exist only in the mind of Euripides' protagonist, are given visible expression. 


\section{Textual Transformation}

In addition to placing more emphasis on the visual, on enacting scenes which were described in words in the ancient drama, and on breaking up long monologues into dialogue, Claus has also toned down the rhetoric of Euripides. Paul Claes uses the term 'trivialise' to characterize Claus' adjustments, ${ }^{22}$ thereby seeking to indicate that Claus often uses rather crude words and expressions from everyday language. Thus Helen is bluntly called the greatest whore in the world (de grootste hoer ter wereld p. 10), probably replacing Euripides' 'cursed by the gods' (19-20). She is also described as a bitch (teef p. 22) and a 'filly on heat' (loopse merrie p. 47), while Aigistos is a geile kikker (a lustful toad p. 11) and een schandknaap van een minnaar' (a scandalous lover p. 14). This vulgarization of language perhaps has its seed in the way in which Euripides sometimes unexpectedly uses prosaic terms in his poetic lines, which may have sounded as shocking to an ancient audience as the deliberately crude language in Claus' play.

The comic effect of the debasement of mythological characters by vulgar descriptions is paired with their own pretentious efforts at elevated speech. Menelaos, for instance, who is a foppish character much concerned with his appearance, adopts facile rhyming couplets which, together with his dandified appearance and Eastern clothing (his first entrance is to the tune of 'In a Persian Market', a well-known tune by Albert Ketelby), ${ }^{23}$ reveals his shallow and inconsequential character:

Eindelijk zie ik mijn vaders huis terug.

De ellende van Troje is achter de rug.

Ah, deze poorten terug te zien, dat maakt me blij.

Alhoewel, geloof me vrij, er is ook treurnis bij. (p. 29)

(At last I see my father's house again, the misery of Troy left behind. Oh, it makes me glad to see these gates again, although, believe me, there is also sadness.)

\section{Structure}

Claus preserves the main structure with its double plot: the first part deals with the innocence or guilt of Orestes and the second with the punishment of Menelaos for his cowardly lack of support for his brother's children. The denouement of both sections is presented in burlesque fashion. The trial of Orestes, which takes place in the assembly of the people, becomes a satire of the game of politics, while the appearance of the god is presented with such irony and lack of awe that the chorus exclaim: 'What a comedy.' Walter Tillemans, the director of the first performance of Claus' Orestes further exploited the ancient deus ex machina ending by presenting the god Apollo with traits of Claus, dressed in a white suit and wearing sunglasses, as Claus

\footnotetext{
22 Claes (1984b, p. 309).

23 Van Nieuwenborgh (1976).
} 
often did. ${ }^{24}$ This choice explicitly credited Claus with providing the denouement of the drama and was very much in line with the lightness of touch suitable for a comedy. Claus' audacious handling of Euripides' text renders him a modern equal of both the ancient deity and the ancient playwright.

Claus' ending also subverts the call to peace of Euripides' Apollo: 'respect Peace, the fairest of the gods' (Waterfield, p. 95). In Claus' version the chorus of female neighbours criticize the elevation of Helen; a queen always lands on her feet. They conclude 'What a comedy!' and Apollo agrees:

Precies, mevrouw.

De geschiedenis herhaalt zich, de eerste keer is het een tragedie, de tweede keer een komedie.

Zo heb ik het nu ook geregeld.

Wat aanvankelijk burgeroorlog

was

en moord en weerzinwekkende

wraak,

heb ik vervangen

door de lachwekkende taak

van huwelijk en regering! (pp. 87-88)

(Exactly, madam. History repeats itself: the first time it is a tragedy and the second time a comedy. I have now ruled it thus. What was initially civil war and murder and repulsive revenge, I have replaced by the ridiculous task of marriage and government!). ${ }^{25}$

This provocative summary of the outcome of the cycle of blood and revenge underlines that Claus' play reduces Euripides' tragedy to the everyday reality of messy modern politics and domestic relationships. It also emphasizes that the elevated genre of tragedy has become banal in the contemporary world. This is underlined when Apollo's pronouncement is followed by loud music and a grand finale of the whole cast joining in a dance.

This ending shocked some contemporary critics, who were perhaps less familiar with Euripides' own provocative interpretations and expected Greek tragedy to be nothing but elevated and solemn. Claes argues that such reactions were exacerbated by the spectacular effects used in the performance. Claus had taken a play in which Euripides himself had boldly challenged some of the traditional approaches to the gods and myth and turned it into a play which also challenged the notions about Greek tragedy of modern audiences. It was also a vibrant play that swiftly alternated colourful scenes, sometimes with a crowded stage filled with movement,

\footnotetext{
24 Claes (1984b, p. 311).

25 This is a reference to a well-known tag from Karl Marx's The Eighteenth Brumaire of Louis Bonaparte: 'Hegel remarked somewhere that all great, world-historical facts and personages occur, as it were, twice. He forgot to add: the first time as tragedy, the second as farce!' (quoted from Fischer 1973: 1678).
} 
and sometimes concentrated on one or two characters and with a slower tempo. In Scene 15, for instance, Elektra is alone but for the Furies and sings a death lament as she has just heard about the sentence passed on her and Orestes by the people's assembly; in Scene 29, Elektra encourages the chorus to stop Helen getting away while Orestes and Pylades are trying to catch her and her Phrygian guards make half-hearted attempts to shield her.

The reviewer Willem Jan Otten in Vrij Nederland (15 November 1977) noted that, while Euripides had written his play against the background of the Peloponnesian War between Athens and Sparta that had been dragging on for more than two decades (431-404 BC), Claus' play was not aimed at critiquing a specific war, but rather against the background of modern society where it seems impossible to integrate people who have become so alienated that they resort to destructive action. This may be as true today as it was forty years ago but it is worth noting that the transgressors are here not punished, but there is a spirit of revelry at the end, just as one finds at the end of ancient comedies.

\section{Claus and Oedipus}

Claus' next engagement with Greek tragedy was once more an interpretation of the Oedipus myth. He had already adapted Seneca's Oedipus in 1971 and in total created no fewer than four plays based on the Oedipus myth. In addition to Oedipus naar Seneca, these plays are Het Huis van Labdakos (1977), Blindeman (1985) and In Kolonos (1986). In discussing Claus' 'oedipodie', ${ }^{26}$ Claes points to other instances in Claus' earlier work, both plays and poetry, where he had already alluded to the myth, but his adaptation of Seneca's Oedipus was his first play fully focused on the myth. Tellingly, Claus chose as the basis of his work Seneca's tragedy which had been roundly reviled by scholars as inferior to Sophocles' masterpiece. It will be useful to offer first a brief overview this earlier play, since as one of Claus' later Oedipus works, Blindeman, is to some extent a reworking of this first adaptation.

\section{Oedipus naar Seneca}

Once again, Claus' conception of the chorus and its role in the play as a whole is very much his own and an integral part of his fundamental reinterpretation. Claes correctly points out that although Claus drew to a remarkable extent from the Oedipus of Ted Hughes, and also from the English translation by E. F. Watling, the use of these intertexts was mostly confined to his poetic formulation of the dialogue, while the overall framework, structure and interpretation are Claus' own invention.

Claus' stage directions and the words of his chorus sketch a post-apocalyptic, scorched world. The plague of the ancient world is described in terms that would fit the destruction caused by a nuclear attack. Like Seneca's Oedipus, Claus'

${ }^{26}$ Claes (1985). 
protagonist feels responsible for the devastation caused in his kingdom. He believes that only God will be able to provide salvation. Claus' radical alteration of the role of the chorus makes it the protagonist of the drama. Members of the chorus also play the roles of the shepherd, the old man Phorbas, Manto, the young daughter and assistant of Tiresias, a slave, Laius and two women. Although the outline of the action is overall preserved, a number of scenes only described in the speeches of the ancient play are acted out in the new version, just as in Claus' Orestes. The live representation is instigated by members of the chorus and results in vivid plays-withinthe-play. The most fundamental change that becomes apparent in the re-enactment is that Claus has made the chorus, the community, responsible for Laius' murder. Because they seek to transfer their guilt to Oedipus, the play gains a new psychological dimension.

In the scene of sacrifice where Tiresias is attempting divination, Oedipus and Jocasta play the sacrificial victims as the chorus place masks of the heads of a bull and a heifer on their heads. Their participation thus already links them to the unnatural symptoms discovered in the extispicy and described by Manto and implicates them in perverted acts. In a further mime, which replaces the description of the necromancy of Laius in Creon's words in Seneca's tragedy (530-658), Laius' spirit appears and accuses Oedipus of being his murderer, and also of having an incestuous relationship with Jocasta. He directly rouses the Thebans to expel Oedipus.

Oedipus is shown as perplexed by the accusation. The chorus accuse him, but in their re-enactment of the scene of Laius' murder, they are again shown to be the actual killers. The audience are consequently aware that this Oedipus is innocent. Sympathy is generated for his suffering. He has become a victim of a plot in which others shift their guilt onto him. Their strategy is so successful that Oedipus himself begins to suspect that he might be guilty. The plot follows the ancient pattern, with the message of the death of king Polybus inexorably leading to Oedipus discovering his true identity. He makes no attempt to evade the guilt for the murder and incest and punishes himself by tearing out his eyes. Seneca's graphic description is taken over by Claus, but, unlike the awestruck account of the ancient messenger (915-79), this chorus is almost gleeful in its telling of the horrific deed. The hostility of the chorus contrasts with the Jocasta's tender love for Oedipus, for instance, when she mentions his 'dearest, strong fingers' (liefste, sterke vingers p. 96). Claus adopted Ted Hughes' innovation that Jocasta hates Laius because he had taken her firstborn from her, but Claus elaborates this aspect of Jocasta's character further and has her acknowledge at the end, when Oedipus arrived in Thebes, that she had already recognized him earlier on by his crippled feet (p. 95). The blame for the incest is therefore hers, as she knowingly married her own son. Oedipus thus emerges as innocent of both crime and sin, but, nevertheless, he has taken on the guilt and inflicted a merciless punishment on himself. The despairing end of Seneca's drama is intensified by the harsh lack of sympathy of Claus' chorus. Claus gives to the chorus the Senecan line, siste, ne in matrem incidas (1051), where Oedipus cautions himself not to fall over Jocasta's body, and which is generally regarded as rather tasteless and melodramatic in its intensification of the gruesome details of the play's resolution with the onstage suicide of Jocasta. They tauntingly exhort him: Val niet over het lijk van je moeder! (p. 99) (Do not fall over your mother's corpse!), thereby 
demonstrating their utter lack of sympathy with his plight. He is under the illusion that he will be taking the plague with him, but, as he leaves, the stage directions have the chorus first dance, and then fall into the same comatose state as at the start of the play, leaving the lingering impression that Oedipus' suffering and sacrifice have been in vain. Claus' recasting of Seneca's drama places human fate and the human condition under human control and leaves us with a pessimistic conclusion about humankind's inherent evil.

\section{Het Huis van Labdakos}

In his second dramatic version of the Oedipus story, Het Huis van Labdakos, Claus made use of elements not only in Seneca's Oedipus, but also in Sophocles' two Oedipus plays as well as his Antigone and Euripides' Phoenissae. There is no chorus, but a large cast of characters taken from all of the five tragedies. The names of the characters are the transliterated versions of the Greek: thus not only Oidipoes, Iokaste and Kreon, but also Eteokles, Polyneikes, Antigone, Ismene, Eurydike, Haimon and Menoikos, as well as Tiresias and Manto. In addition, Laios himself appears, as does the Oracle, in the shape of a nubile young woman. At the start, the last two are on the scene, which represents a large room into which the various characters flee for refuge from the disaster threatening the city until they are all assembled on stage. In the course of the action, it emerges that Iokaste hates Laios because he was homosexual and delighted in seducing young men. The birth of Oidipous was the result of him raping her when he was drunk. He wanted Oidipous killed to eliminate his seed. She loves Oidipous and immediately recognized him when he returned to the city. She is, therefore, as in Claus' adaptation of Seneca's Oedipus, guilty of initiating and knowingly entering into the incestuous relationship.

The production was set in the twentieth century, with the cast wearing modern clothes. ${ }^{27}$ There are many references anachronistic to the ancient world, such as talk about radio and TV, Menoikos playing with a model aircraft, Ismene referring to her Chanel suit and Oidipous being blinded by halogen lamps. It is noteworthy that the role of the gods has been omitted, adding to the impression of the play being drawn closer to the contemporary world. The action with its causes and effects is on a purely human level.

As the whole house of Labdakos is gathered in the room, it becomes the scene not only of the discovery of who murdered Laios and of Oidipoes' departure to Kolonos (which turns out to be a bed surrounded by foliage right at the back of the stage), but also of the struggle for power between Polyneikes and Eteokles, and their deaths, as well as of Antigone's refusal to obey Kreon's decree not to bury her brother and of the suicides of Antigone, Haimon and Menoikos. At the end of the play, Eurydike and Ismene survive, while Kreon is busy composing a speech to relay to the people the misfortune that has befallen his family. The last words, however, are given to Laios:

27 Janssens (1986, p. 28). 
Families verscheuren elkaar

Zoals de beesten niet eens doen.

Er zijn geen tranen meer, denkt men.

Vergeet het. Er zijn steeds nieuwe tranen.

Volkeren vergaan, volkeren van larven

en van mensen.

En neiuwe volkeren schieten op

met diezelfde vragen

voor de larven, voor de mensen.

(Families tear each other apart, as not even animals do. People think that there are no more tears. Forget it. There are always new tears. Nations perish, nations of larvae and of humans. And new people rise up with the same questions for the larvae and for the people.)

This rather pessimistic message summarizes the thrust of the play. There does not seem to be hope of redemption. The catastrophic effect of the series of family murders, slaughter and suicides certainly illustrates a cycle of death and destruction, but it is questionable whether condensing the material of so many ancient tragedies into one play strengthens the impact. Het Huis van Labdakos is dedicated to the director, Frans Marijnen. Apparently, he had asked Claus for a play on the Theban myth cycle. ${ }^{28}$ Claus obliged and completed the work within three weeks. Critics like Claes found it to be lacking cohesion and depth. He compared it to the type of family sagas in TV series like Dallas and Dynasty and judged it unconvincing as social critique. ${ }^{29}$ Janssens likewise offered harsh criticism of the play and the performance. He castigated this work as closer to a parody of the ancient works than a coherent modern work. ${ }^{30}$

\section{Blindeman}

In 1985, Claus returned to the Oedipus myth for his third version, Blindeman. He reworked his previous adaptation of Seneca's tragedy and gave it an even more personal and modern stamp in a post-apocalyptic setting. Oedipus explicitly becomes a play-within-the-play. Blindeman, the title, refers not only to the traditional blinding of Oedipus, but also to the Tiresias character, Tiete, (named 'Tits' for his androgynous nature) and to one of the victims of the nuclear disaster which forms the background to the play. The audience at the first presentation were made to experience the utter blackness of lack of sight by the sudden plunging of the theatre in complete darkness: even the lit 'exit' signs were extinguished for a few minutes as the play opened. ${ }^{31}$ This shock prepared the audience for the sombre nuclear winter to follow and also to the blindness of some of the characters, notably Oedipus.

\footnotetext{
28 Claes (1985, p. 509).

29 Claes (1985, p. 509).

30 Janssens (1986, pp. 28-30).

31 Decreus (1992, p. 57).
} 
The play is set at a water sports centre outside Ghent, where a group of survivors have gathered in the blackened landscape. There is an extensive preamble, which familiarizes the audience with the characters who each play dual roles: their everyday ones as well as a character in Oedipus, which they have seen produced and decide to perform in order to pass the few remaining days of life they have left. The characters do not have a script of the ancient tragedy, but they are able to perform the play as they still have the ability to speak and remember. There is no separate chorus, but the actors have the core roles as in Seneca's tragedy: Omer is Oedipus; Yolande, Jocaste; Lannoo, Laius; Tiete, Tiresias; the Chef is Creon; Vorten, Phorbas; Katte Manto; Franske the shepherd and Rosten a slave. There is one additional character, Marie, who does not have a named role in their Oedipus but hands Oedipus the knife with which he blinds himself and Jocaste the knife to kill herself. She also provides a kind of choral counterpoint with her laments for the loss of her daughter, first blinded and then killed in the nuclear catastrophe. She also represents a Christian strand, which is not fully worked out, but is evoked in her bearing the name of the mother of Christ (with whom Oedipus is, to some extent, identified in the conclusion of the play). The other actors at times assume the role of the chorus, as they combine to accuse Oedipus of the murder of his father. Oedipus is thoroughly demythologized. He is not able to solve the riddle himself, but needs the help of the others to do so.

There are elements of farce in this adaptation, notably in the language register and in incidents such as a game of blind man's buff to which Omer/Oedipus is subjected once he has been blinded. Claus has written the dialogue in a local dialect. ${ }^{32}$ The crude language and coarse words prevalent in most of the play are in contrast to the higher register the characters sometimes assume when playing their secondary parts. In some cases, their dialogue then reproduces and echoes that of Claus' adaptation of Seneca's Oedipus. For instance, in Blindeman Omer, as Oedipus, repeats the sententia of the Senecan adaptation:

Een koning kan niet regeren

als hij bang is voor de haat.

Angst is het

die koningen vrijuit laat gaan. (p. 62)

(A king cannot rule if he is afraid of hatred. It is fear that allows kings to prosper.)

However Omer's words are more earthy and coarse:

Iemand die benauwd is voor de haat

van de mensen, kan nie regeren.

Een koning blijft in leven

als zijn onderdanen in hun broek doen

van benauwdheid. (p. 61)

${ }^{32}$ Claes (1985, p. 511). 
(Someone who is afraid of the hatred of the people, cannot rule. A king stays alive if his subjects soil their pants from anxiety).

The changes and the debasement of the language fittingly illustrate the disenchantment of the modern characters. The vulgarity of the foul-mouthed characters also emerges from their frequent use of words such as 'gat' (arse) and 'kloten' (balls).

Claus maintains the innovation of his previous versions: The Jocasta character's hatred of Laius is again caused not only by his exposure of their son, but also by his homosexuality. Her complicity in and responsibility for the incest, are maintained; the community who have killed Laius again manage to persuade Oedipus/Omer that he is the murderer although he killed only Laius' servant. Omer's acceptance of responsibility for the crime and his willingness to atone for his wrongs by blinding himself are again shown to be pointless. The rest of the community, who are guilty, are not even impressed by his sacrifice, nor does it bring about a change in their dire existence. A link with the suggested futility of Christ's sacrifice for humankind is made explicit by Claus specifying Easter as the day on which a nuclear explosion destroyed their former existence. The day of resurrection thus becomes a day of death. Oedipus' sacrifice is portrayed as just as pointless as that of Christ. This pessimistic view of the moral incapacity of modern humanity casts this modernization of the Oedipus myth in a light of profound disillusionment. Neither in the play nor within the play-within-the-play is there any hope or redemption.

\section{In Kolonos}

A final engagement with the Oedipus myth is presented by Claus' adaptation of Sophocles' Oedipus at Colonus, first produced in 1986 with the simplified title In Kolonos. His play follows the structure of the Greek drama but there is no chorus. This is partly due to the restriction to only two actors placed upon Claus by the director, Julien Schoenaerts. ${ }^{33}$ Sophocles makes use of three actors and a chorus of elders of Colonus. Claus skilfully succeeds in making a convincing adaptation of the ancient drama in spite of the constraint of not having more than two actors on stage at a time. The different methods applied in overcoming this limitation and creating a cohesive new version of Sophocles' final tragedy will be pointed out below. As Claus' last interpretation of the Oedipus myth, In Kolonos forms a fitting finale to his depiction of Oedipus in his previous plays as innocent of the crimes of parricide and incest with which he is traditionally associated. As in the Greek tragedy, his end, although not quite an apotheosis, is shrouded in mystery and surrounded by an aura of sanctity, as it is reported in In Kolonos that his end was without pain. In this way, he is recompensed for the suffering endured in life and confirmation is offered that this was unjust.

Claus chose again to make use of transliterated Greek names in In Kolonos (Oidipoes, Polyneikes and Kreon). He preserves the characters of Antigone, Theseus and

${ }^{33}$ Ector (1989, p. 39). 
Ismene but combines the roles of the Countryman and Messenger in a 'Landman' who also acts as messenger. Claus starts the play in the same way as Sophocles, with Oidipoes arriving on the stage, led by Antigone. As he could not introduce a third actor, the Countryman does not appear to provide information about the setting - Oidipoes does that himself. It is only when Antigone has left the stage that the Countryman comes on. This play places considerable demands on the skills of the second actor: Oidipoes is on stage for the greatest part and the second actor has to play all the other male and female parts.

Some parts of the choral lyrics are incorporated into the dialogue, others are cut. For instance, Oidipoes is given the lines praising the beauty of Kolonos (p. 309), which Sophocles's chorus sing (pp. 668-719). As Oidipoes has just been given a guarantee of protection by Theseus, the words reflect his feeling of security and gratitude. Claus deals with the problem of Oidipoes addressing his friends when there is no chorus or other character on stage, except Kreon or Polyneikes, by letting him direct his appeal to the audience as his allies, (for instance pp. 312, 318). This, of course, makes for closer audience involvement. Claus deals with the abduction of Oidipoes' daughters in a masterly theatrical way. At the end of the confrontation with Kreon, the theatre is darkened and warlike sounds are heard. When the lights come on again, Antigone comes on stage and tells her father how Theseus released her and Ismene from Kreon's clutches. Although In Kolonos is pared down compared to the Greek original, it is still a coherent and cohesive play, and Claus managed to make some effective alterations, partly compelled by the small cast, but also influenced by his predilection for play-within-the-play scenes. This technique is deployed in the final scene where Claus has a thunderclap and Oidipoes is calling for Theseus, telling him 'my hour has come' (Mijn uur is gekomen.' p. 321). Oidipoes then leads the way off stage. Next, the countryman comes on and relates, as the Messenger does in Sophocles, how Oidipoes purified himself. But then there is another thunderclap and Oidipoes himself appears 'in an unreal light' (p. 324) and speaks his own words as he takes leave of his daughters. Thus, Claus allows the audience to see Oidipoes at the moment before he disappears. The play concludes with the Landman stating that nobody knows whether God took him up to heaven or whether he was welcomed into the earth, but it is certain that he suffered no pain. Claus thus concluded his last engagement with the Oedipus myth by giving his protagonist a blessed ending. It is notable that in this last play Oidipoes insists that he was innocent of crime and sin, and that Jocasta had not known they were committing incest. It is fitting that Oidipoes should be rewarded at the end for the immense suffering he endured in life.

By ending his 'oedipodie' in this way, Claus has maintained and justified his treatment of the myth in the preceding three plays. His interpretation of the innocence of Oedipus boldly exonerates him from the guilt of killing his father. In this sense, Claus' Oidipoes justly is awarded a special, blessed transience from life to death. 


\section{Medea in Modern Suburbia - Borgerocco or De dood in Borgerhout}

Euripides' Medea is one of the ancient Greek tragedies that, from antiquity onwards, has inspired a huge number of adaptations in different countries and languages all over the world. While Hugo Claus did not transform it into a modern play, he used it as the basis for a libretto for an opera set in contemporary Belgium. He was commissioned by the Royal Flemish Opera to write it for the composer Frederic de Vreese; however, it has not (yet) been performed, even though the text was published in 1998.

The title is derived from a combination of Borgerhout, a district of Antwerp, and Morocco. The district is notorious for drug trafficking conducted by gangs of Moroccans who have settled there. Claus has changed his Medea, who in the Greek tragedy is a 'barbarian' Colchian to a Moroccan immigrant in modern Belgium. She is called Fadoea and her Jason is a Belgian called Jan Decoster. Fadoea is not a princess, Jan is not a hero; they are ordinary people trying to make a living in the contemporary world. The stage directions specify the setting as a labourer's house, where, as the action starts, a party to celebrate the marriage of Jan with Fadoea is in progress. His parents are present but do not join in the merriment because they do not approve of their son marrying a 'negress' ${ }^{34} \mathrm{He}$ has presented their union to them as a marriage of convenience as he is being paid one hundred thousand franks as a 'dowry'. Being married to a Belgian citizen will enable Fadoea to remain in Belgium legally. Still, the parents disapprove of the marriage, not only because they are racist, but also because they do not like the fact that their son is obviously in love with his bride. The father moreover sees something sinister in the young woman from 'dark Africa' (p. 13). While the opening shows the young couple in love and starting their life together, the audience is also shown Fadoea making Jan swear an oath that he will always be true to her.

The plot follows the familiar pattern of Euripides' tragedy, but Jan's discontent with his marriage is increased by his own lowly and badly paid job on the refuse collection team while he sees 'brown guests' lounging around the streets. He contends that the state should send these refugees back to their own countries. Meanwhile, Fadoea's attempts to adapt to her new home include learning to speak Flemish, a realistic touch not found in the ancient drama. The couple has twin sons, one called John after Jan's friend, and the other Ahmed, after Fadoea's father.

Further scenes are set five years later when Fadoea is busy with domestic tasks and looking after the young boys, but Jan has taken to spending time at the Café de Kroon. Their unhappy domestic circumstances are interrupted by scenes representing the life of the city. First Fadoea's brother arrives, bloodied by an assault by what he calls Jan's friends from the café. He was demonstrating at the embassy about injustices in his home country. Jan's attitude is devoid of sympathy and he shows all the intolerance towards immigrants associated with right-wing groups. It is clear that the relationship between Fadoea and Jan is at breaking point. An additional

\footnotetext{
34 See Van Zyl Smit (2014) for discussion of Medea dramas where the protagonist is represented as of a different race.
} 
scene, invented by Claus, centres on Jan's friend John and a blond Belgian girl called Godelieve, the daughter of the owner of the Café De Kroon. Godelieve is the counterpart of Jason's bride, daughter of Creon in the ancient tragedy. She has come to consult Fadoea because she is pregnant, allegedly by John, and believes Fadoea can help her abort the foetus. Fadoea agrees to do this for a fee, but clearly suspects that the baby is Jan's. The next scene sees Jan informing Fadoea that he wants to leave her. They can divorce in a civilized way and he will marry Godelieve, get a job at the café and pay her alimony every month. When Fadoea reacts with rage and refuses to fall in line with his wishes, he threatens to have her brother deported and her own Belgian citizenship revoked. She must leave their house within a week.

The next scene has Fadoea sitting in the living room surrounded by the dead bodies of Jan's racing pigeons. Jan's mother arrives and is horrified by this carnage. She wants to take the children away, but Fadoea at last gives vent to her rage and chases the old woman out of the house with curses. She then calls the boys and says it is time. What follows is a scene in which she shows her tender love for the children, yet the chocolate milk she gives them to drink makes them fall asleep and die. As she sings an Arabic song, she is carried away by a group of people dressed in Arabic dress.

Jan enters to find the lifeless bodies of his children. There is no final confrontation between Fadoea and Jan, simply the shock of her vengeance and the separation of the two worlds which have been shown to be totally irreconcilable.

Claus removed his characters from the royal sphere of the ancient drama and toned down the role of magic and the gods. Although Fadoea has enough knowledge of herbs to ensure that she renders Godelieve sterile when she aborts her foetus, she does not use further magic. In modern Belgium, the exotic features of magic and divine intervention would be out of place. In keeping with many modern reworkings, the killing of the children is represented as euthanasia. In contrast to the spectacular departure of Medea in the ancient version, Fadoea is transported away by her own compatriots. With all these changes, Claus has shifted the emphasis from a love betrayed to the incompatibility of two cultures. This dimension is, of course, also part of the ancient version, which features Medea marked as a non-Greek barbarian. In this libretto, Claus has once again, (re-)focused the adapted play on a theme relevant to his time and environment and highlighted an intractable problem of the contemporary world.

\section{Conclusion}

It is clear from the above discussion that Greek tragedy provided Hugo Claus with a fertile source of material that could be transformed to reflect themes relevant to his own time. As an experienced dramatist he knew how to alter the formal structure of the ancient plays to create modern works that engaged the attention of his audiences, not only by innovative staging, but also by introducing issues that appealed to them while still retaining the resonance of their mythical background.

In his Orestes, he exploited Euripides' daring approach to one of ancient Greece's classical myths to produce a scathing indictment of the superficial treatment of 
serious issues in modern society. Equally bold is his prolonged engagement with another of the Greek myths best known to modern literature, that of Oedipus. His refusal to accept the canonical version of Oedipus as a man guilty of parricide goes hand in hand with a dismissal of the gods' control over human life and accentuates the unjust punishment of Oedipus in Sophocles' tragedy. This is a reaction sometimes shared by modern readers and audiences and memorably celebrated in Steven Berkoff's adaptation of the Greek tragedy. ${ }^{35}$ Claus shows that we do not have to accept the ancient Oedipus but can express our own interpretation of him as victim. His version of Oedipus' peaceful transposition in In Kolonos thus becomes a fully deserved reward for the injustice to which he has been subjected in life. In Claus' Oedipus plays, as he had done earlier in his Thyestes, he moreover issues stark warnings about the danger of nuclear destruction and other ecological disasters threatening the world and caused by human beings. In his adaptation of Medea, Claus touches on another pressing problem in the modern world: the assimilation of refugees from third world countries in Europe. Although others have preceded him in emphasizing the theme of this tragedy as a conflict between races, he makes the point clear by (re-)situating it in a specific location with which his audience would be familiar. All these issues remain pertinent in the twenty-first century and demonstrate that Claus's treatment of ancient drama continues to speak to the modern world.

Open Access This article is distributed under the terms of the Creative Commons Attribution 4.0 International License (http://creativecommons.org/licenses/by/4.0/), which permits unrestricted use, distribution, and reproduction in any medium, provided you give appropriate credit to the original author(s) and the source, provide a link to the Creative Commons license, and indicate if changes were made.

\section{References}

Berkoff, S. Greek, London, 1980.

Claes, P., 'Claus' oedipodie', in Dietsche Warande \& Belfort, 130.7, 1985, pp. 506-12.

Claes, P., Claus-Reading, Antwerp, 1984a.

Claes, P., De Mot Zit in de Mythe: Hugo Claus en de oudheid, Amsterdam, 1984b.

Claus, H., Blindeman, Amsterdam, 1985.

Claus, H., Borgerocco of De dood in Borgerhout. Libretto for an opera. Amsterdam, 1998.

Claus, H., Het Huis van Labdakos, 229-87, in Toneel V, Amsterdam, 1993.

Claus, H., In Kolonos, in Toneel IV, Amsterdam, 1993, pp. 289-325.

Claus, H., Oedipus, naar Seneca, Amsterdam, 1975.

Claus, H., Orestes, naar Euripides, Amsterdam, 1976.

Decreus, F., 'Van Oedipus naar Blindeman, van Seneca naar Claus,' in Dodelijke dikke Wolken, eds. R. van der Paardt and F. Decreus, Leidse Opstellen 18, Leiden, 1992, pp. 23-73.

Ector, J., 'Claus met Oedipus “in Kolonos”, Dietsche Warande \& Belfort, 134.1, 1989, pp. 39-41.

Fischer, E. ed., (tr. Anna Bostock) Marx in His Own Words, London, 1970.

Hall, E., 'Introduction' in Waterfield, 2001, pp. vii-xxxix.

Hughes, T., Seneca's Oedipus, London, 1969.

\footnotetext{
35 A prime example is Berkoff's adaptation in Greek where Eddy is free to celebrate his love for his Wife/mother at the end of the play.
} 
Janssens, M., 'Een Orestes Bewerking van Hugo Claus' in Dietsche Warande \& Belfort, 1976, pp. 776-80.

Janssens, M., 'Hugo Claus - Labdakos en Jessica' in het Naakt en het Roze, literaire kritiken, Amsterdam, 1986, pp. 27-33.

Kelly, A., Sophocles: Oedipus at Colonus, London, 2009.

Otten, W. J., Vrij Nederland 15 November 1977.

Porter, J. R., Studies in Euripides' Orestes, Leiden, 1994.

Slaney, H., The Senecan Aesthetic, Oxford, 2016.

Van Nieuwenborgh, M., ,Orestes van Claus in KNS‘, De Standaard, 18/19 September, 1976.

Van Zyl Smit, B., 'Black Medeas', in Looking at Medea, ed. D. Stuttard, London, 2014, pp. 157-66.

Van Zyl Smit, B., 'Seneca Tragicus in the Twentieth Century: Hugo Claus' Adaptations of Thyestes, Oedipus and Phaedra', in Brill's Companion to Roman Tragedy. ed. G. W. M. Harrison, Leiden, 2015, pp. 330-347.

Waterfield, R., (translator), Euripides, Orestes and Other Plays, Oxford, 2001.

Watling, E. F., (translator), Seneca: Four Tragedies and Octavia, Harmondsworth, 1966.

Watling, E. F., (translator), Sophocles: The Theban Plays. Harmondsworth, 1947.

Willink, C. W., Euripides: Orestes, Oxford 1986.

Wright, M., Euripides: Orestes, London, 2008.

Publisher's Note Springer Nature remains neutral with regard to jurisdictional claims in published maps and institutional affiliations. 